\title{
An Analysis of Factors Affecting Duration of Planning Works
}

\section{Introduction}

The economic and social development of every state is closely associated with a pursued planning policy. Spatial planning in Poland is run at three levels: country, regional and within the commune. The interaction of all three levels of planning is crucial for social, economic and infrastructure development. Spatial planning allows us to adjust the elements of the public space, in order to create a coherent and logical wholeness.

The most important document is arising at the level of a commune and a local land management plan. The local plan is a treasury of information about the space it determines trends of the development of the commune as well as a way of carrying the ownership transfer out is shaping [6]. The objectives of the local plan are above all: establishing allocating areas, determining the manner of developing object areas, as well as determining terms and conditions of their building development and establishing arranging investment of public purposes [8].

The adoption of a resolution on adopting the local land management plan (the Polish acronym: MPZP) is bringing the wider consequences with it. Taking steps is forcing the commune to fulfill assumptions made in the local plan. Authorities of the commune through records of the local plan are trying to improve the spatial structure of the commune, to make it more attractive among potential investors and residents of the commune. The period, from the adoption of a resolution about setting about drafting the local plan to the moment of its passing by the legislative branches of the commune, is long and at many times is protracting in the time.

In the present article an attempt of the analysis of factors and conditions which influence the period needed for drafting the planning important document has been made.

* AGH University of Science and Technology, Faculty of Mining Surveying and Environmental Engineering, Krakow, Poland 


\section{Characteristics of the Study Area}

The Krzeszowice Commune is located in the Małopolska Province, in the Cracow District. It is placed on the top one spot amongst the communities of the Cracow district in terms of the size, for its area over 139 thousand $\mathrm{m}^{2}$. The population reaches the level close to 32 thousand. The commune is located in the immediate vicinity of Cracow's urbanized area (the registered office of the mayor is located about $25 \mathrm{~km}$ from the center of Cracow) and Silesian (about $50 \mathrm{~km}$ from the center of Katowice). It is an additional asset of the commune, which is gaining the interest of investors.

In the objective of protection of endangered plant species and animals and keeping peculiar natural habitat types of the European continent based on two EU directives a European Ecological Web "Nature 2000" was formed, in the commune Krzeszowice was distinguished a few of such areas. An unification of the system of the conservation of nature is an aim of this undertaking on territory of states being involved in the European Union [3].

\section{Spatial Planning at Municipal Level}

As mentioned above, in Poland it is possible to distinguish three levels of the spatial planning [8], they are as follows:

- spatial planning at the municipal level,

- spatial planning on the level of the province,

- and spatial planning on the level of the country.

The planning led correct politics on three levels of administration of the country, in the significant degree influences the supply and demand on the market of the real estate. Correct stimulating the spatial order depends on whether it enables to take action being used for an implementation of an investment project of public purposes [1].

The spatial planning on the local level is own setting the commune which it should carry out with the due diligence, since it is a base of the pursued spatial politics and has a significant effect on the forming of surroundings. In the direct way it influences the community, is having an influence on a space of the man and his plans towards had real estates. It is tied together also, with the fact that it is regarding low areas relatively: of the commune, the town, the housing estate, a few villages or the single village, so in the comprehensive way it is possible to examine and to verify possibilities of the given area.

Two consecutive levels of the planning, provincial and domestic, refer to the wide scale, they are embracing with one's reach the entire country or the individual of the administrative division of the top stair-province. Planning on these levels is focusing its attention on public purposes about supra-local, domestic meaning, the 
border space and other issues associated with the area, for which they are being taken. Exchanged levels of the planning are creating the cohesive integrity, lives of the society affect improvement.

On each of the mentioned above rungs of the spatial planning a relevant document, in which main thoughts are included and the plans associated with the completion of deliberate undertakings, are being drafted (Fig. 1). Planning studies differ between themselves, above all in the reach on which they are having an influence, what is also affecting information included in them and their accuracy [2].

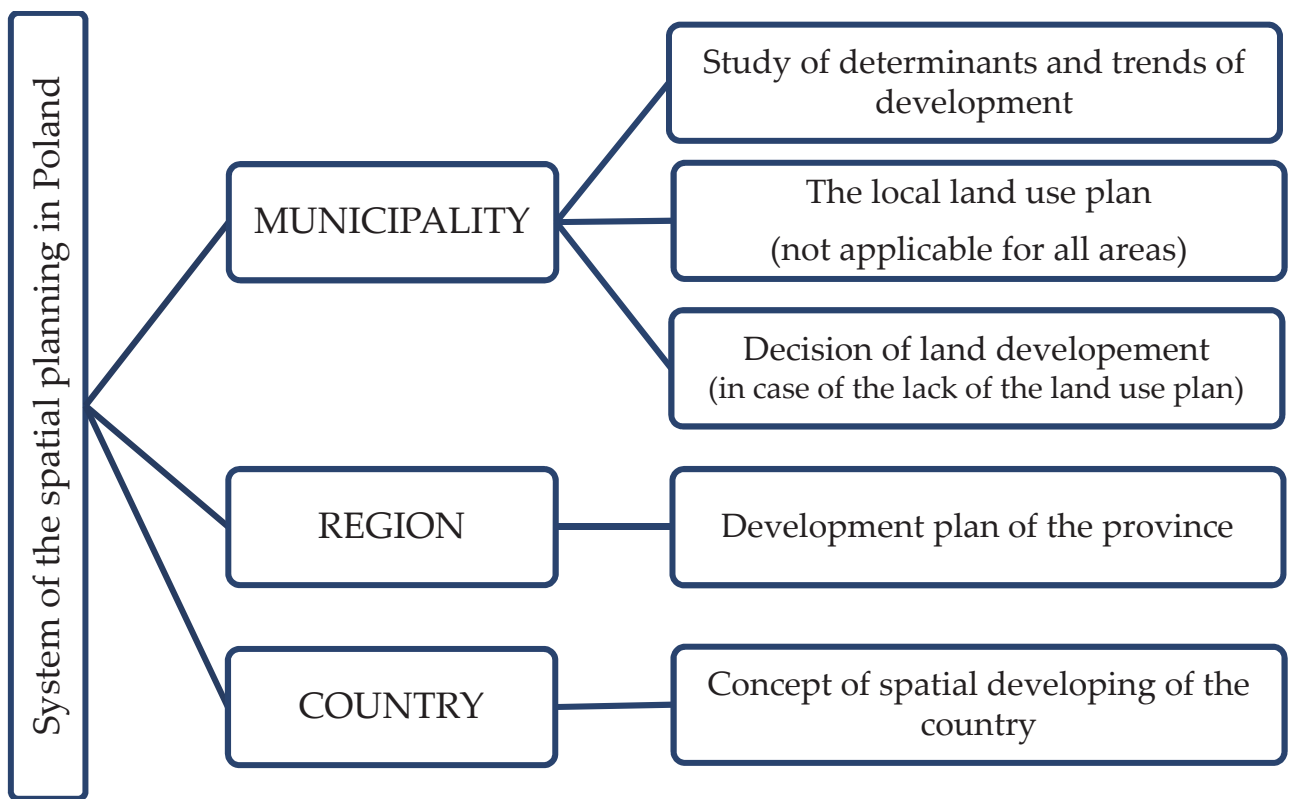

Fig. 1. Significant planning documents incurred at various levels of spatial planning

At the commune level of planning, three documents will matter greatly: the decision of land development, the study of the determinants trends of the development (study) and most essential for society, a local land use plan (more briefly local plan).

Their legal nature is a basic difference dividing the study and the local plan. The local plan is an act of local law, which means that is binding organs and society legally, one should obey its regulations, is triggering legal effects.

In contrast, the study isn't an act of local law and isn't triggering legal effects. Its high rank results from the fact that one should include its regulations at drafting of the local plan, authorities of the commune in order to implement amendments to the local plan, must take them into account in the study. The second essential feature of the study, it is being prepared obligatorily for the whole area of the municipality. Next, the local plan isn't a compulsory document and the commune can prepare it with 
fragments for individual areas put within the limits of its self-government. The study, as the drafted obligatorily document, let coordinate works on the local plan and notice, which areas require the drafting or the revision of local land management plans.

The records included in the local plan are affecting later forming of the space. Local plans, compared with the study, are characterized by a large degree of accuracy. Contents of plans explicitly determine the principles of divisions of the real estate, character of developing the real estate and also the influence the value of the property.

\section{Characteristics of Planning Works Conducted in the Area of the Commune}

The Krzeszowice Commune is taking action to meet the expectations of residents as well as is trying to perform own tasks imposed by the act on commune self-government [9]. Forming of the spatial order is one of fundamental tasks, determined in the act.

With reference to the above, the commune is trying to adapt records in acts of the spatial planning led on its area to current needs and to care about their topicality. Through implementing appropriate changes or update of the entire document, the commune is trying to implement the spatial politics of par excellence.

In the schemes (Figs 2,3) in the form of an axis of the time stages was described, on which it is possible to single out the procedure for compiling of planning documents in the area of the Krzeszowice Commune. With maroon color stages associated with the coming into existence or the amendment to the Study were emphasized, while black color - the update and drafting local plans for various areas of Krzeszowice Municipality.

\subsection{Study Being in Force}

Works on the Study being applicable in the Krzeszowice Commune were begun on the basis of the resolution of the city council No. LI/ 419/2006 from 27 October 2006 on the accession to the preparation of renovation of the Study of the City and Krzeszowice Communes. An adaptation of the Study to the requirements of the act on the spatial planning and development was an aim of taken action. Taking the temporal distance into consideration for the year previously applying to the Study, passed in 1999, the document was subjected to the comprehensive update. The commune mayor announced over a year later about setting drafting of the Study. The process of creating the project Study lasted nearly three years, in the first quarter of 2009 it was laid out for the public inspection. In a fundamental way, for a period of creation the Study affected in need of taking into account the applications received, which influenced in the result is needed to announce setting about drafting the Study, as well as the need of investing received arrangements and the opinion from competent institutions and organs. 
In relation to numerous remarks filed in the draft of the Study, a need for its repeat of laying out to the public inspection, what took place in the last quarter of 2009. The current Study was admitted by the City Council in Krzeszowice with resolution from 28 January 2010 No. XLVI/ 369 / 2010 on passing the amendment to the Study, what was included in Figure 2.

Nearly three and half a year took for organs of the commune to draft the Study. Quoting the fact, that the Study isn't an act of the local law and isn't having legal effect, it is a long procedure. However, at this point it belonged in order to emphasize that many assumptions at the Study will proceed directly to the local plan. Therefore, it is the document which is drafted cautiously and to analyse all data in order in to minimize the need of its constant updates in the later period. Often the need of the earlier amendment to the Study causes delaying works on local plans.

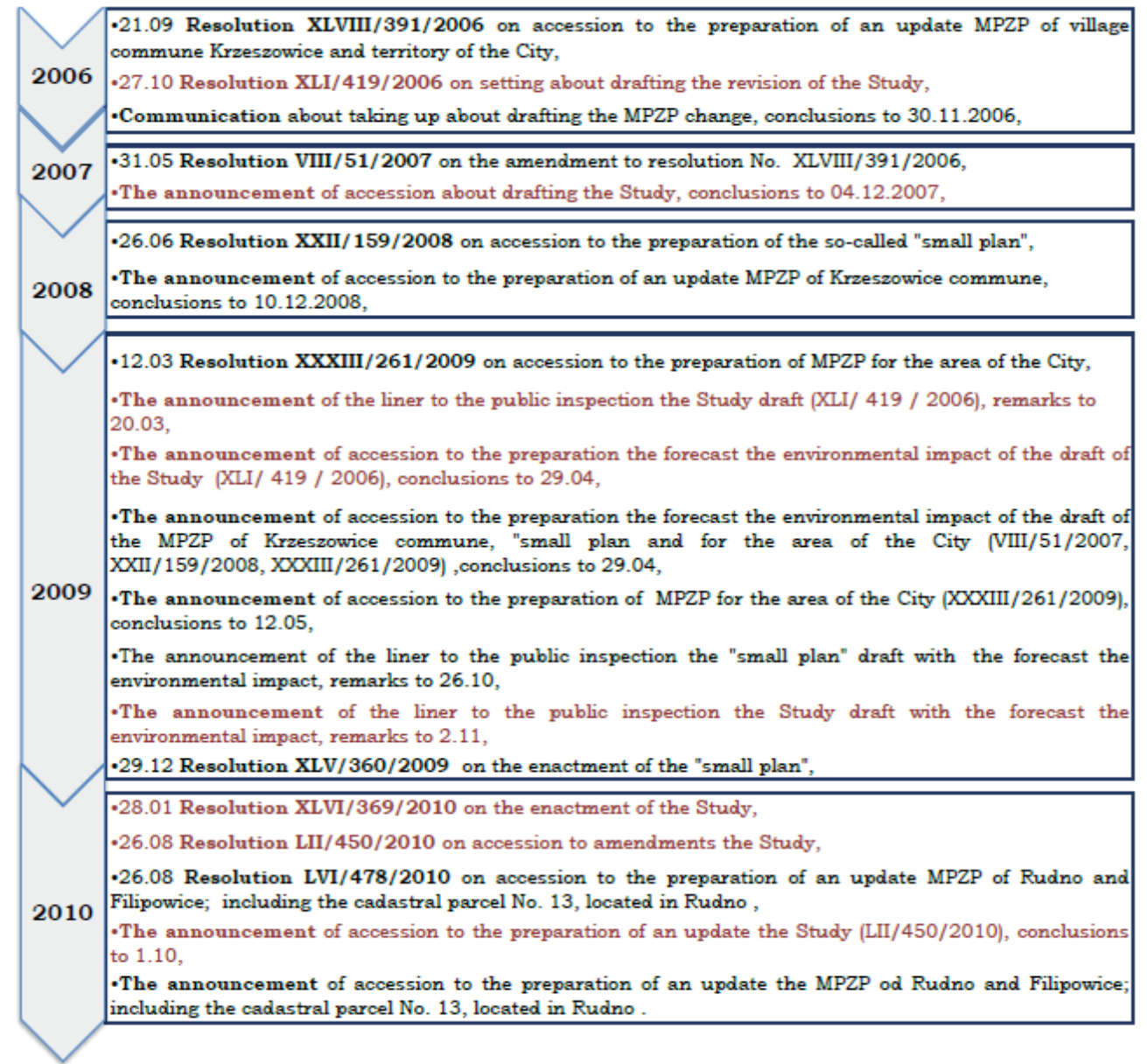

Fig. 2. Action of organs of the commune, from period 2006-2010, influencing for passing the Study and local plans 


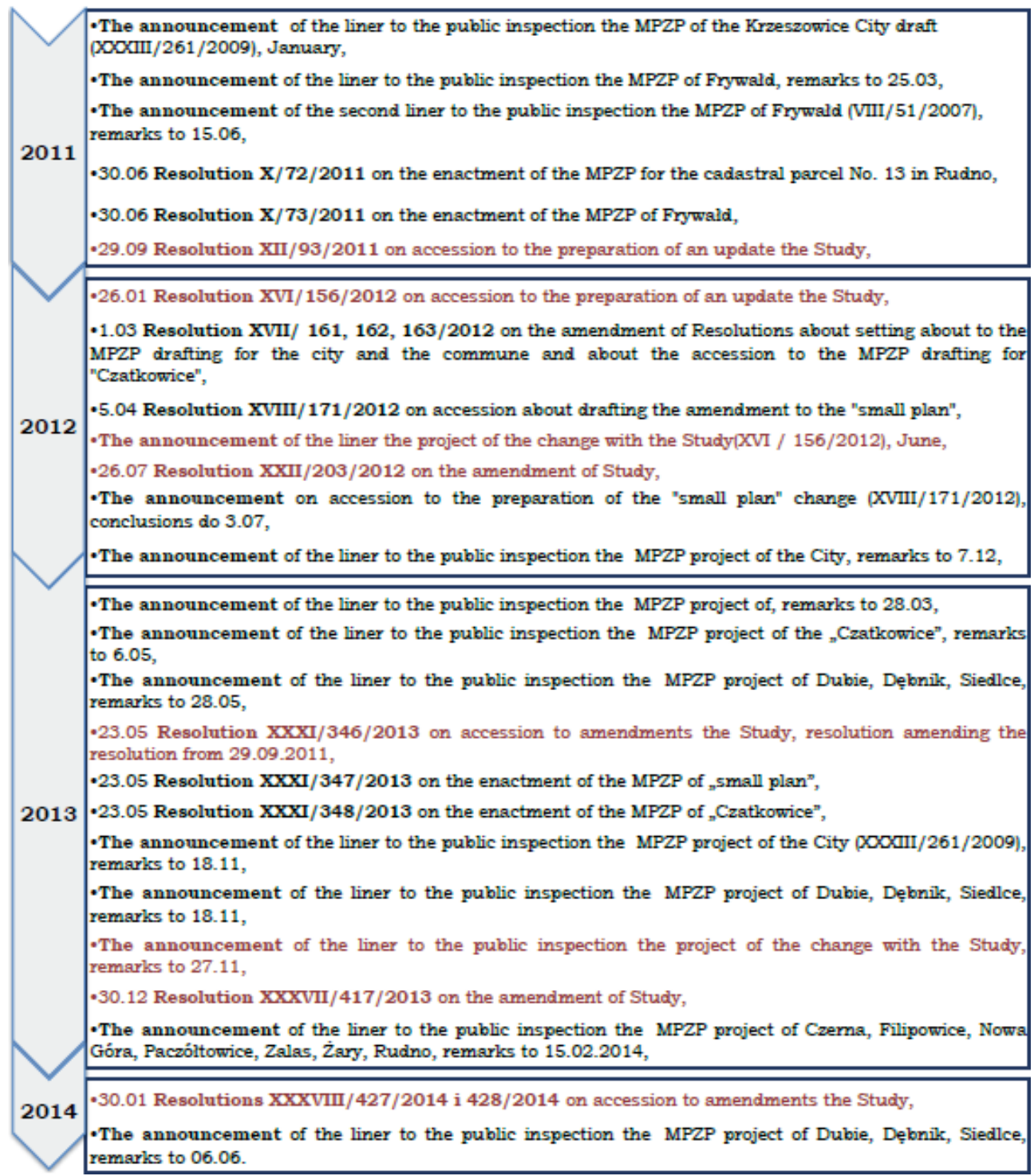

Fig. 3. Action of organs of the commune, from period 2011-2014, influencing for passing the Study and local plans

On the example of the Krzeszowice Commune it is possible to spot the core of the problem, in spite of the thorough update, already half a year after passing the Study, a need of its change followed, a picture of the Study was subjected to the alteration. Next resolutions on the accession to draft the changes in the Study are being issued every year, from the moment of passing it, result from current needs of synchronizing records of the Study and arising local plans. They are caused among 
others from the need of widening the graveyard in the Tenczynek whether Paczółtowice, changes in allocating of areas after the former mine in Miękinia whether of extending the area of the use of the substantiated deposit for the limestone mine "Czatkowice".

The legitimacy of passing the exchanged changes arises from the provisions of the law, because showing above elements is essential to enable to enter them into drafted local plans. Why it failed in the initial stage to consider all aspects? In some cases, for example for extending the area for the limestone mine "Czatkowice", had to wait until a changed the decree of the Governor of Małopolska of the resolution of the Lesser Poland province assembly which will enable the use within the limits of proven reserves. And so coincidences are happening, in which other, led parallel proceedings, are making it impossible to enter information into the Study.

\subsection{The Activities Carried out in the Field of Local Plans}

According to data obtained from the Department of the Management of Assets and Municipal Spatial Planning the area of the Commune is 13937 ha from what 12267 ha is embraced in local plans what constitutes about of $88 \%$ of the surface of the entire municipality. It is a very good result being a fact overcome up to the attention, that according to statistical data from 2011, run by the Ministry of Transport, Building and Water Management, the share of areas for which drafted local plans were based on the Act from 2003 in Poland was estimated on the level of the 52.4\%.

Plans in the commune were subjected to the update and works on them weren't still finished. In Figure 4 a progress of works on the revision of local plans was presented in the Krzeszowice commune according to the state from 10 April 2014.

Entry into force of the act from 2003 about the planning and spatial Management it caused by the fact that the land use plan of the city Krzeszowice had stopped applying at the beginning of 2004 [8]. It forced the municipalities into taking up update works on plans passed before 1 January 1995. If the new plan wasn't passed before the end of 2003, old local plans lost the force of law.

On the sitting of the City Council in Krzeszowice on 21 September 2006 they decided to take action of planning for the revision of local plans for rural municipalities and drafting the local plan for the area of the city. Resolution No. XLVIII/ 391/ 2006 on the accession to prepare an update of local development plans of the Krzeszowice Commune: Ostrężnica, Frywałd, Zalas, Nawojowa Góra, Nowa Góra, Miękinia, Czerna, Paczółtowice, Żary, Dębnik, Dubie, Siedlce, Wola Filipowska, Sanka, Rudno, Filipowice and Tenczynek and the area of the Krzeszowice City, covered by the plan changes after 1995.

This resolution was amended on 31 May 2007 by the City Council in Krzeszowice with resolution No. VIII/ 51/2007. The alteration consisted in excluding of the part concerning the city and replacing "excluding areas provided with changes of plans after 1995" on "and of areas provided with changes of plans after 1995". However, announcing local plans of the Krzeszowice Commune about the accession 
to the update was made public in the second half of 2008, the interested parties filed applications to 10 December 2008. Conclusions of citizens concerned most often reclassifying lands. Since the adoption of the first resolution on the accession to the preparation of local plans renovation, more than two years passed. This period should be shorter what could precipitate works on drafts of plans, because authors of the document would get the alternative of earlier acquainting themselves with conclusions and answers to it.

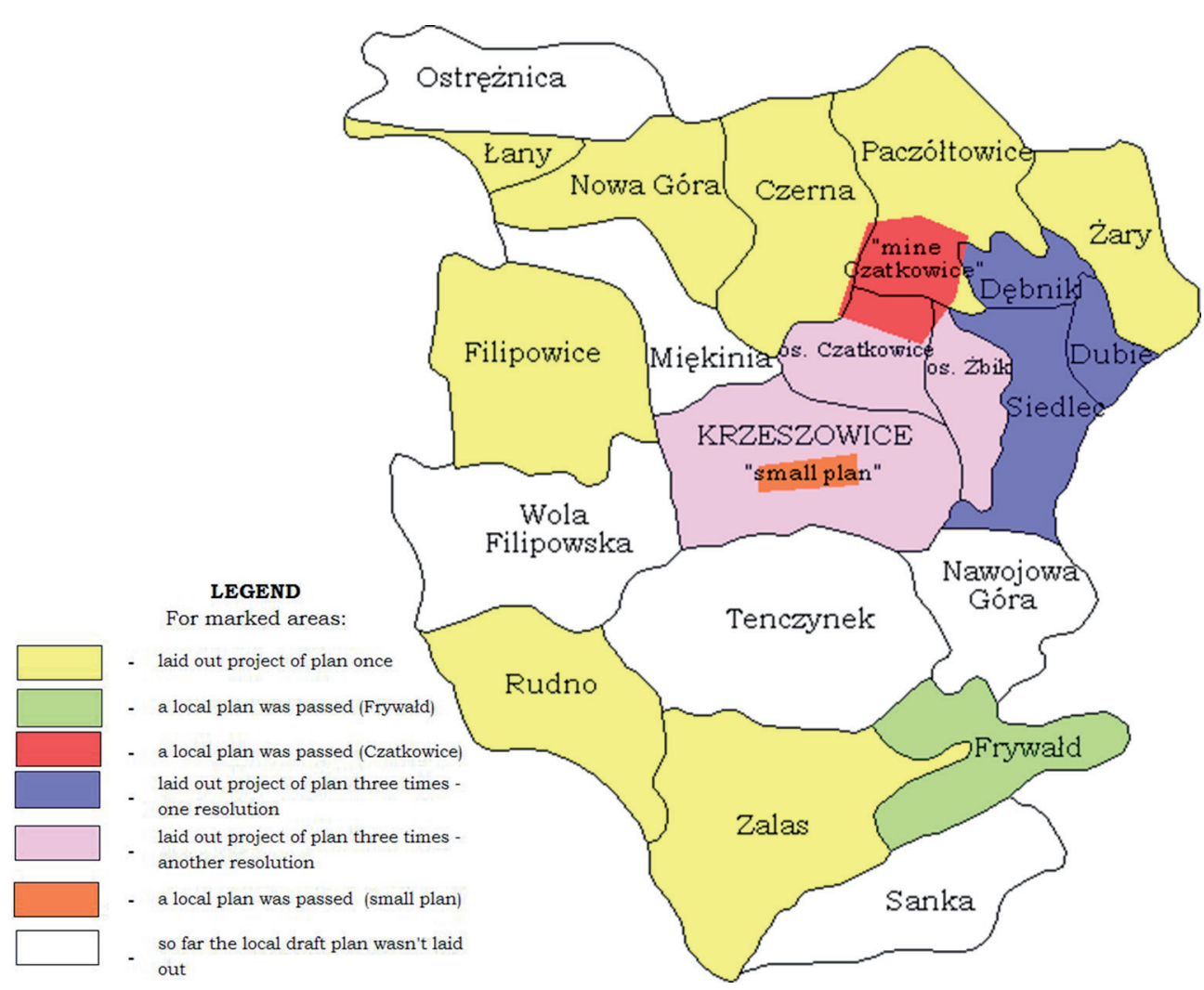

Fig. 4. Progress of planning works in the commune Krzeszowice

Simultaneously the commune council on 26 June 2008 adopted a resolution on the accession to the preparation of the so-called "small plan". It is including the fragment of the city limited by Krzeszowice: from the north national road 79, Kościuszki street, from the west with the Krzeszówka river, from the south with parcel No. 1614 (area of Polish State Railways), from the east with parcels belonging to premises of the State-owned Railways with following No. 1703 / 1, 1703.2, 1704 / 6 and 1614, with the area of over 9 ha. The area with drafted local plan an enclosure to the resolution the accession to the preparation of the local plan is presented (Fig. 5). 
Accepting of the above resolution was dictated by providing the possibility of carrying out a project for a scientific - research what could bring benefits to the municipality. The draft plan was accepted with a resolution of the city council on 29 December 2009. It is worthwhile pointing out that in spite of little area works on the plan lasted close one and a half years what clearly highlights folded character of the procedure and its labour intensity. It should emphasize the fact that to the local draft plan remarks brought in didn't stay, which definitely speeds up works on local plans.

Over two years later, from passing the "small plan", they started to change it. They abandoned the scientifically-research project. According to the minutes of the XVIII No. of the session of the City Council from 2012 they stated, that: "adapting records of the plan is necessary for development potentialities and the completion of services in this area widely understood commercial, affecting an economic boom of the Commune, as well as the interest of potential investors" [5]. Persons working on local plans again had to focus their attention on the recalled area, what works on other projects had to be quietened, but not ceased by. However, after the year managed to pass the time new "small plan".

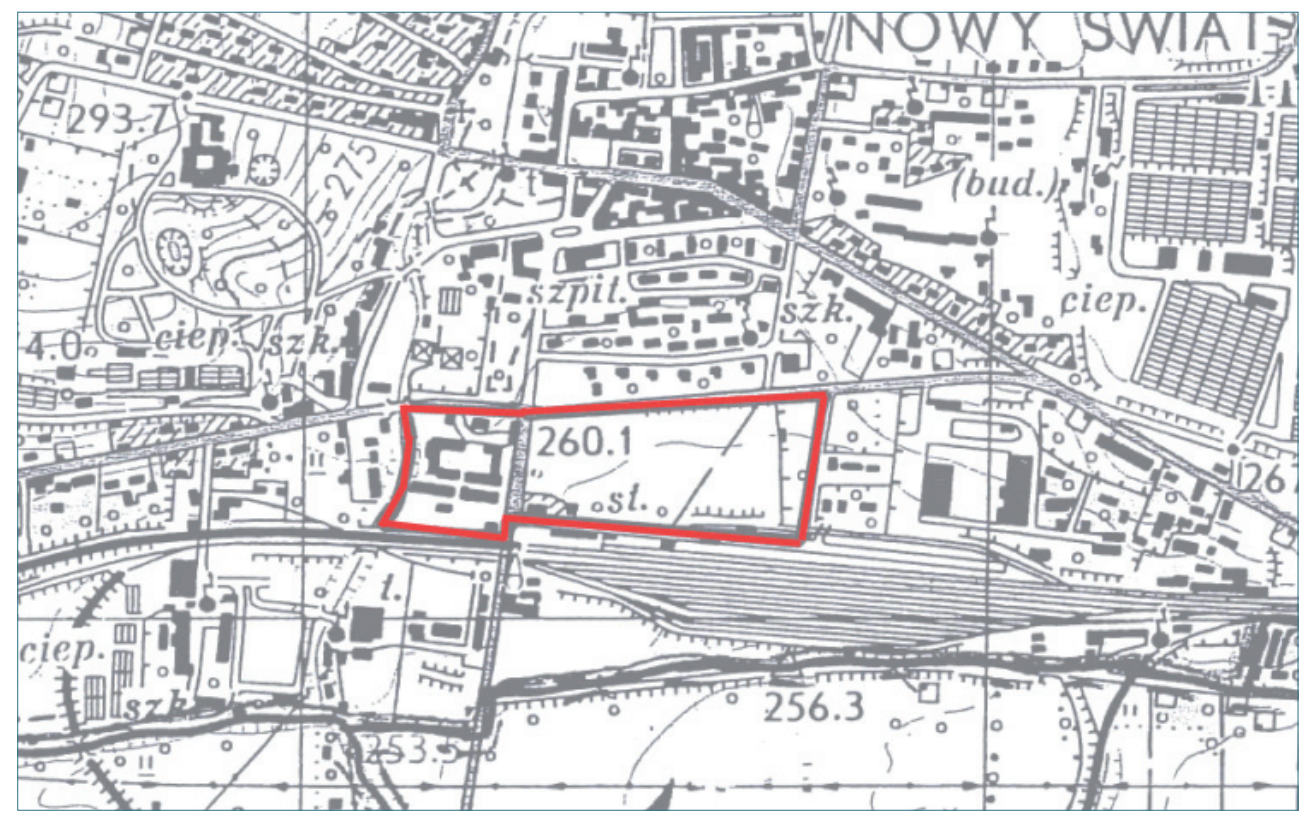

Fig. 5. Border of spread area with "small plan", shown in red Source: enclosure to resolution No. XVIII/ 171 / 2012

In March 2009, they started work on the local plan for the area of the Krzeszowice City, an area of the "small plan" was excluded. At the same time, according to records of the act from 3 October 2008 [10], a need to draft projects for environmental 
impact assessment Study, as well as drafted local plans arose, what influenced on a period of drafting planning documents.

Planning work above the local plan for the City area has been lasting for five years. The project was subjected three times to public discussion. Periods in which residents could become acquainted with them were described in Figure 2 and 3. Drafting the local plan in the area of the city is a difficult task, it is hard to find all sides to a solution which would be satisfying. The amount of remarks carried into the draft of the Krzeszowice street plan is being given in hundreds what significantly effected for lengthen the time taken to procedures. Organs of the commune expected reducing their number while third laying out. They tried positively to investigate remarks brought in earlier, however residents weren't favourably disposed this way, how authorities expected it. Certainly this procedure won't end on third laying out. To lodge protests of residents in the form of remarks to the draft plan, it is probably the most important factor influencing for delaying planning action.

It should be also emphasized, that the minimal duration of laying out is a period of 21 days. According to the Administrative Court in Poznań sentence from 1 July 2011 [11], it was assumed that the period of laying the local draft plan out for the public inspection was falling on days, in which interested entities have a real access to the draft plan. Citizens must have a guaranteed possibility of getting acquainted with the document laid out by at least 21 days, therefore they are acknowledged that they should be working days of the office. The time limit for the submission of remarks to the local draft plan, not perhaps to be shorter than 14 days, counting laying the draft plan out from the day, in which the period was finished. Taking above factors into consideration, the closing of a stage associated with laying out and collecting remarks lasts two months.

The action of the commune is connected mainly with implementing solutions of different implementations which are aimed at the recovery of the economy, as well as favourable of investment. Therefore, drafting local plans for little areas, set to the completion of the specific project are happening what took place with the "small plan".

This situation is also regarding to the local plan drafted for the cadastral parcel No. 13 in Rudno. For the parcel, the City Council passed the plan, in the process enabled the investor to take action above the project - with the expansion of a film studio complex. The plan included an area of 0.40 hectares. It is worth underlining, that for such little area, of row of several acres, the planning procedure remained close for a year. The need of obtaining right opinions and arrangements, as well as the application to public information about setting of drafting the local plan and about laying the draft plan out, causes, that it is hard to shorten the planning procedure.

The local development plan for the rural administrative unit Frywałd was the first planning study, which was carried out in response to the resolution on the accession to draw up the revision of local plans of the Krzeszowice Commune. 
The planned area of this local plan is 573.77 ha. With one's reach area spread through rural administrative units in its administrative boundaries. Laying out of the first version of the draft plan took place in March 2011, however, with the end of June the plan was already passed. Works proceeded efficiently, interested entities carried ten remarks into the draft plan of the local rural administrative unit Frywałd. The draft plan was laid out twice. With the cooperation of organs of the commune and residents, it is possible to efficiently and effectively conduct the operations.

It should be emphasized that for a period of drafting the local draft plan many factors are resulting in requires to underline. Gathering the right initial materials is needed, among others of map undercoats, analysing submitted applications by citizens, and especially analysis of the possibility of development of area, that action is time-consuming.

The further example is regarding area, for which the local plan was drafted in order to enable the "Czatkowice" mine to take certain actions. Representatives of the "Czatkowice" mine put forward a proposal to the Mayor of Krzeszowice for giving consent to widen border of use of the substantiated deposit. In order to make efforts for getting the concession for the use of the deposit, investment must be led into the local plan. As already mentioned, information about widening border of use also need the amendment to the Study, as deciding had to be taken earlier into account into the Study, which definitely affects the planning action. Resolution No. XVII/ 161 / 2012 from 1 March 2012 concerning the accession to the preparation of the local plan in newly designed area border for the mining operation documented deposit "Czatkowice" began direct actions. On 6 May 2013 passed the time limit for the submission of remarks, however with the end of the month the Municipal Council voted the resolution through on passing the local plan. Coverage a newly designed border is spreading through areas being in the town Paczółtowice, Czerna and Dębnik. A need to update the border of areas, for the plans on this region, will be drafted.

This investment will have considerable influence on the economic situation in the commune, among others through takings from property taxes intended to enlarge the mining area and additional places of employment in mining units what will result in the improvement in the standard of living of residents. If authorities of the commune didn't pass a resolution on the accession to the preparation of the local development plan for the described area, then an application of representatives of the mine would be reviewed at preparing the local draft plan for the city Krzeszowice. The local plan so far wouldn't be passed, and fossil representatives still didn't have a possibility of obtaining of the concession for the use of the deposit.

Bearing in mind the above considerations, reducing area, for which the draft plan will be drafted is advantageous local. It is forming with minimizing any claims of residents, since enables conducts of indepth analyses. Undoubtedly the flaw in such a solution is above all costing increase of works connected among others with financing on with the project and agreeing on the plan. 
According to results of the analyses conducted by the Ministry, almost $30 \%$ of plans have been adopted after three-year-old works. Authors of analysis of the state of planning works are concluding, that the "tendency of growing extending the planning procedure is being provided clearly about progressing problems with passing local plans" [7].

Obtaining the right opinions and arrangements and conducting the appropriate forecasts of the influence of the plan on the environment are influenced by the period of planning work, it required with Act. The duty of laying the local draft plan out for the public inspection is also contributing to extend the planning procedure, it is the main factor of extending the planning procedure. Interested persons have a possibility of getting acquainted with the document and an acts of defiance, when disagree with records of the local draft plan. A need to implement amendments to the planning document and to retry certain steps of the procedure is occurring. It is worth to emphasize that those responsible for passing the local plan should have mediatory abilities in order to reach an agreement with residents of the commune.

\section{Conclusions}

Basing on conducted analyses, it is stated, that in spite of labour intensities of action associated with drafting the local plan, authorities of the Krzeszowice Commune are trying to perform task, which was entrusted them by the legislator. They are passing land use plans successively. However, period of running of planning works is growing longer. Municipality authorities proceeded, at the end of 2006, for the revision of local plans for rural areas. However, in the first quarter of 2014 a local plan was passed for one village - Frywałd and two plans for little areas ("small plan" and "Czatkowice"). For three towns - Dubie, Dębnik and Siedlec was drafted draft plan local, which discussions were already three times conducted above. For seven next towns, Czerna, Filipowice, Nowa Góra, Paczółtowice, Zalas, Żary, Rudno, a draft plan was prepared local. The first laying out to public discussion took place at the end of 2013. For the project it was possible to file remarks to 15 February 2014. Draft local plans, which could by subjected to lay out, have not been prepared for remaining villages yet.

Planning action above drafting the local plan for the area of the Krzeszowice City was commenced in 2009, at the end of 2013 has not been passed yet. For the past four years has been drawn up a draft plan, appropriate opinions and remarks were received as well as it subjected three times to public laying out. The need of repeated discussing a problem and negotiating an optimal solution causes, that failed within this period to pass the local plan for the area of the city. Residents are carrying numerous remarks into the draft plan what causes that the process of passing it is delaying. Rural areas affect this problem to a lesser extent. 
Bodies of local governments in spite of willingness and needs associated with passing local plans are obligated in order to abide by regulations of the Act. It influences the time consumption of planning action. Keeping the minimal number of days of laying the draft plan out, or also filing remarks to it are needed, is specified in the Act and results in extending the time essential to realize the procedure of passing the plan. Therefore, shortening the period, in which a citizen has the possibility of getting acquainted with the draft plan local and of filing remarks, at next laying out, could have a positive effect on a procedure of passing the plan.

Passing the act of the local law for the "small plan", about the surface of the row of a few hectares, lasted several months. The need of conducting the sequence of analyses and research, as well as preserving the procedure of drafting the local plan, of dates above all required, influences the time devoted to gathering planning documentation. Passing local plans for little areas is a way to hasten the procedure. Then action is proceeding more efficiently and lasts more briefly.

Concepts of developing the space thought over and implemented into the reasonable manner can diametrically improve the economic situation of commune, have a positive effect on the natural environment and its protection and the improvement in social relations. Covering the whole territory of the commune of current local land use plans is the aim, which local authority aspire gradually. In order to precipitate works, authorities of the commune are deciding to draft local plans for smaller areas, because passing them lasts more briefly than for the area of a few rural administrative units.

\section{References}

[1] Bieda A., Hanus P., Hycner R. (red.): Geodezyjne aspekty planowania przestrzennego i wybranych opracowań projektowych. Wydawnictwo Gall, Katowice 2012.

[2] Cymerman R. (red.): Podstawy planowania przestrzennego i projektowania urbanistycznego. Wydawnictwo Uniwersytetu Warmińsko-Mazurskiego w Olsztynie, Olsztyn 2009.

[3] Gmina Krzeszowice, [on-line:] http://www.krzeszowice.pl [access: 24.11.2014].

[4] Ministerstwo Transportu, Budownictwa i Gospodarki Morskiej, [on-line:] http://www.transport.gov.pl [access: 24.11.2014].

[5] Protokół nr XVIII z sesji Rady Miejskiej w Krzeszowicach w dniu 29 marca 2012 roku.

[6] System informacji prawnej, [on-line:] https://sip.legalis.pl/index.seam [access: 24.11.2014].

[7] Śleszyński P., Górczyńska M., Dręgowska A., Zielińska B.: Analiza stanu i uwarunkowań prac planistycznych w gminach na koniec 2011 roku (etap I). Polska Akademia Nauk, Instytut Geografii i Przestrzennego Zagospodarowania, Warszawa 2012. 
[8] Ustawa z dnia 27 marca 2003 roku o planowaniu i zagospodarowaniu przestrzennym. Dz.U. 2012 poz. 647 as amended.

[9] Ustawa z dnia 8 marca 1990 roku - o samorządzie gminnym. Dz.U. $2001 \mathrm{nr} 142$ poz. 1591 as amended.

[10] Ustawa z dnia 3 października 2008 roku o udostępnianiu informacji o środowisku i jego ochronie, udziale społeczeństwa w ochronie środowiska oraz o ocenach oddziatywania na środowisko. Dz.U. 2008 nr 199 poz. 1227 as amended.

[11] Wyrok Wojewódzkiego Sąu Administracyjnego w Poznaniu z dnia 1 lipca 2011 roku. Sygn. akt 482/11.II SA/Po. 